\title{
Scrotal Circumference and Testicular Morphometric Characteristics of the Camel (Camelus Dromedarius) in the Semi-Arid Environment of Northern Nigeria
}

\author{
Circunferencia Escrotal y Características Testiculares Morfométricas del Camello \\ (Camelus Dromedarius) en el Ambiente Semiárido del Norte de Nigeria
}

"Ibrahim Ali Abdullahi; "Hassan Al-Hassan Musa \& "Aliyu Jibril

ALI ABDULLAHI, I.; AL-HASSAN MUSA, H. \& JIBRIL, A. Scrotal circumference and testicular morphometric characteristics of the camel (Camelus Dromedarius) in the Semi- Arid Environment of Northern Nigeria. Int. J. Morphol., 30(4):1369-1372, 2012.

SUMMARY: Reproductive tract of 12 camels (Camelus dromedarius) were used to evaluate testicular morphometry. The testicular morphometric characteristics measured were scrotal circumference (in situ), paired testis weight, epididymal weight and mean epididymal length, testis volume, and testis density. There were no significant difference $(\mathrm{p}>0.05)$ between the left and right organs, but there were numerical differences between all the parameters. A highly significant positive correlations $(p<0.05, p<0.01$, $p<0.001)$ exist between the scrotal circumference, testicular and epididymal morphometry, except for testis density which is non- significant ( $p>0.05$ ). It was concluded that testicular morphometry would provide reliable information in predicting sperm production of camels in the semi arid environment.

KEY WORDS: Camels; Scrotal circumference; Testicular morphometry; Epididymis; Semi-arid.

\section{INTRODUCTION}

The potentials of camel as a food producer in the arid and semi- arid areas of the world are well recognised. They have provided man with animal protein and energy and give nomads immense mobility (Knoess, 1979). They are animal genetic resources and constitute indispensable natural resources that must be properly managed (Djemmali \& Alhadrami, 1998). Although many studies praised their unique characteristics especially under the most stressful condition, the absence of reliable genetic strategies is a real handicap for camel development. By virtue of these attributes and potentials, the role of camel as food animals is being accepted globally and the camel scientist (Faye \& Esenov, 2005) stated that camel has unfathomed potentials for satisfying humans future dietary and medicinal needs.

Camels are known to be seasonal breeders, and their reproductive efficiency under natural pastoral condition is low (Skidmore, 2008). Their fertility characteristics have not been fully documented to facilitate effective genetic improvement. In the male for instance, there is the need to establish measurable criteria for judging breeding soundness and guiding selection of males for breeding.
Morphometric analysis on the testes of any species or breed is necessary in predicting not only sperm production but also of the storage potentials and fertilizing ability of the breeder male. Similarly, Osinowo et al., (1981) and Togun \& Egbunike (2006) reported that the testes size is a good indicator of the present and future sperm production in bulls. There is at present a paucity of information in the available literature on the testicular morphometric characteristics and their application in the prediction of good sire in camelids. Testicular measurement and the changes that occurs during growth of the testes from birth to maturity have however been well documented for goats (Bitto \& Egbunike, 2006), rams (Setchell, 1978) and bulls (Willis, 2001; Dyce et al., 2002). The aim of the present study is to evaluate the testicular morphometry in camel in the semi-arid environment of northern Nigeria.

\section{MATERIAL AND METHOD}

Sample collection. Reproductive tracts of 12 matured camels were obtained in toto after slaughter from the Kano central

\footnotetext{
* Department of Animal Science, Kano University of Science and Technology, Wudil, Nigeria.

** Department of Animal Science University of Maiduguri, Maiduguri, Nigeria.
} 
abattoir. Collections were done between 0500 and 0700 hours on 3 separate days. The reproductive tracts were immediately brought to the laboratory covered in ice and were processed on the same day.

Testicular morphometry. Scrotal Circumference was evaluated using a piece of thread placed at the greatest diameter and measured on a rule as reported by Osinowo et al. (1981). All weighing of samples was done using a highly sensitive balance in the laboratory.

Paired testes weight and epididymal weight. The testes and epididymis was separated free of adhering connective tissues and fats. The left and right testes and epididymis were measured separately and their weight recorded. The epididymis was then divided into caput, corpus and cauda segment.

Testes and Epididymal volume. The volume of the testes and epididymis were measured volumetrically using the Archimedes principles of water displacement in a measuring cylinder and result recorded.

Testes density. The tested density was calculated from the testes and volume and expressed as g cc-1: Testes density $=$ Testes weight $(\mathrm{g}) /$ Testes volume $(\mathrm{cc})$.

Tunica albuginae weight. The tunica albuginae was then peeled off each testis after cutting the testes in halves and the weight value recorded.

Statistical analysis. Data collected were subjected to student $t$-test and the one way analysis of variance (ANOVA) and correlation analysis (Steel \& Torry, 1996).

\section{RESULT AND DISCUSSION}

The results of the morphometric characteristics of camels and their derivation were summarized in Tables I and II respectively. The mean scrotal circumference, paired testes weight, paired epididymal weight, mean epididymal length, mean testis volume and mean testis density were $23.73 \pm 1.34,147.69 \pm 25.39,33.68 \pm 2.42$, $27.39 \pm 0.79,68.79 \pm 11.55$ and $1.10 \pm 0.04$ respectively, while the epididymal segment were caput (17.08 \pm 1.00$)$, corpus ( $6.90 \pm 0.49)$ and cauda $(9.70 \pm 0.39)$. There was a great similarity between the overall means of the paired left and right parameters (Tables I and III) of testicular morphometry, although numerical differences exist.

However, there is no available literature that describes the testicular morphometry of camels, but Osman \& el-Azab (1974) reported that the mean testis of camels weigh between 80 and $104 \mathrm{~g}$ which is comparable with the result of the present study. More so, Sisson \& Crossman (1969) reported that the testes of the camels are much smaller than those of the stallion, bull, ram and boar. Contrary
Table I. Morphometric characteristics of the reproductive organs of camel (Camelus Dromedarius) $(\mathrm{n}=12)$.

\begin{tabular}{lc}
\hline Parameters & Mean \pm sem \\
\hline Scrotal Circumference $(\mathrm{cm})$ & $23.73 \pm 1.34$ \\
Right testis weight $(\mathrm{g})$ & $78.46 \pm 12.96$ \\
Left testis weight $(\mathrm{g})$ & $69.66 \pm 12.53$ \\
Paired testis weight $(\mathrm{g})$ & $147.69 \pm 25.39$ \\
Right epididymal weight $(\mathrm{g})$ & $16.71 \pm 1.41$ \\
Left epididymal weight $(\mathrm{g})$ & $16.79 \pm 1.34$ \\
Paired epididymal weight $(\mathrm{g})$ & $33.68 \pm 2.42$ \\
Right tunica albuginea weight $(\mathrm{g})$ & $10.11 \pm 0.97$ \\
Left tunica albuginea weight $(\mathrm{g})$ & $9.92 \pm 1.12$ \\
Paired tunica albuginea weight $(\mathrm{g})$ & $20.02 \pm 2.02$ \\
Right caput weight $(\mathrm{g})$ & $8.28 \pm 1.06$ \\
Left caput weight $(\mathrm{g})$ & $8.80 \pm 0.96$ \\
Paired caput weight $(\mathrm{g})$ & $17.08 \pm 1.00$ \\
Right corpus weight $(\mathrm{g})$ & $3.87 \pm 0.55$ \\
Left corpus weight $(\mathrm{g})$ & $3.03 \pm 0.37$ \\
Paired corpus weight $(\mathrm{g})$ & $6.90 \pm 0.49$ \\
Right cauda weight $(\mathrm{g})$ & $4.56 \pm 0.50$ \\
Left cauda weight $(\mathrm{g})$ & $5.14 \pm 0.47$ \\
Paired cauda weight $(\mathrm{g})$ & $9.70 \pm 0.39$ \\
Right epididymal length $(\mathrm{cm})$ & $13.41 \pm 1.83$ \\
Left epididymal length $(\mathrm{cm})$ & $13.98 \pm 0.52$ \\
Mean epididymal length $(\mathrm{cm})$ & $27.39 \pm 0.79$ \\
Right testis volume $(\mathrm{ml})$ & $75.50 \pm 12.19$ \\
Left testis volume $(\mathrm{ml})$ & $62.08 \pm 11.34$ \\
Mean testis volume $(\mathrm{ml})$ & $68.79 \pm 11.55$ \\
Right testis density $\left(\mathrm{g} / \mathrm{cm}^{3}\right)$ & $1.03 \pm 0.04$ \\
Left testis den sity $\left(\mathrm{g} / \mathrm{cm}^{3}\right)$ & $1.19 \pm 0.08$ \\
Mean testis density $\left(\mathrm{g} / \mathrm{cm}^{3}\right)$ & $1.10 \pm 0.04$ \\
\hline
\end{tabular}

s.e.m $=$ standard error of means.

to the earlier report by Osman \& el-Azab that corpus epididymis is the largest region in size, the present study reveals that the caput epididymis is the larger than the corpus epididymis. This is similar with the reports of Bitto \& Okpale (2006) in bulls and Ugwu (2009) in bucks.

Table IV shows the correlations between the scrotal circumference and the testicular morphometric characteristics. The scrotal circumference had a highly significant positive correlation with testes weight $(\mathrm{r}=$ $0.887, \mathrm{p}<0.001)$, epididymal weight $(\mathrm{r}=0.743, \mathrm{p}<0.01)$, tunica albuginea $(r=0.758, p<0.01)$, testes volume $(r$ $=0.817, \mathrm{p}<0.001)$ and epididymal length $(\mathrm{r}=0.602, \mathrm{p}$ $<0.05$ ), except for the relationship with testes density which was negatively correlated.

Studies by Osinowo et al., (1977), Nwakalor \& Obasi (1991), Bitto \& Okpale and Ugwu had earlier reported similar relationship between scrotal circumference and testis, epididymal, and tunic weight in other species of animals elsewhere. There were also positive correlations between testicular and epididymal 
Table II. Derivations from the morphometric characteristics of the reproductive organs of camels (Camelus Dromedarius) (mean \pm s.e.m).

\begin{tabular}{lr}
\hline Measurements & \multicolumn{1}{l}{ Values } \\
\hline Paired tunica albuginea weight (\%) & $14.92 \pm 0.99$ \\
Paired testis weight & \\
Paired epididymal weight (\%) & $26.92 \pm 2.81$ \\
Paired testis weight & \\
Paired caput epididymal weight (\%) & $13.45 \pm 1.66$ \\
Paired testis weight & \\
Paired corpus epididymal weight (\%) & $5.39 \pm 0.65$ \\
Paired testis weight & \\
Paired cauda epididymal weight (\%) & $8.23 \pm 1.0$ \\
Paired testis weight & \\
Paired caput epididymal weight (\%) & $50.59 \pm 2.90$ \\
Paired epididymal weight & \\
Paired corpus epididymal weight (\%) & $20.88 \pm 1.79$ \\
Paired epididymal weight & \\
Paired cauda epididymal weight (\%) & \\
Paired epididymal weight &
\end{tabular}

s.e.m $=$ standard error of mean.

morphometry $(r=p<0.05, p<0.01, p<0.001)$, except for testicular density $(r=p>0.05)$. The non-significant correlation coefficient observed for testis density with almost all morphometric characteristics studied agreed with the report of Togun (1981) and Togun et al., (2006) which asserted that testicular characteristics cannot be predicted from testis density.
The good and positive correlation of scrotal circumference, testis weight, epididymal weight and length and other morphometric characteristics (except for testis density) would be a reliable predictor of sperm producing ability and fertility of camels, since testis weight is known to be highly correlated with sperm reserves in the testis or epididymis, and this is a direct reflections of testicular integrity for sperm production (Osinowo et al., 1977), Ogwuegbu et al., (1985), Adeyemo et al., (2007). Similarly, Okwun et al., (1996) reported that males with larger testis tend to produce more sperm. Therefore, it is concluded from these results that testicular morphometric characteristics could be used to predict the sperm production capacity in live camels, and reliable selection for breeding based on the testicular morphometry is possible.

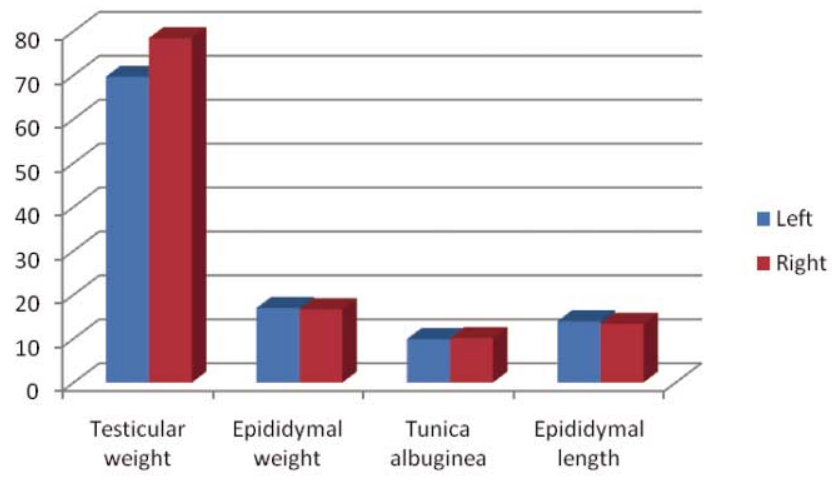

Fig. 1. Left and right testicular and epididymal morphometry in camels (Camelus Dromedarius).

Table III. Derivations (ii) from the morphometric characteristics of the reproductive organs of camels (Camelus Dromedarius).

\begin{tabular}{lccc}
\hline Measurements & Left & Ratio of left /right organs & Level of significance \\
\hline Testis & $100.00 \pm 00$ & $105.90 \pm 4.60$ & Ns \\
Epididymis & $100.00 \pm 00$ & $101.30 \pm 7.91$ & Ns \\
Tunica albuginea & $100.00 \pm 00$ & $103.91 \pm 11.66$ & Ns \\
\hline
\end{tabular}

(mean \pm sem). $\mathrm{ns}=$ not significant.

Table IV. Correlations between scrotal circumference, testicular and epididymal morphometry in camels (Camelus Dromedarius) (mean \pm sem).

\begin{tabular}{|c|c|c|c|c|c|c|c|}
\hline & 1 & 2 & 3 & 4 & 5 & 6 & 7 \\
\hline 1. Scrotal circumference & 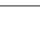 & $0.887 * * *$ & $0.743 * *$ & $0.758 * *$ & $0.817 * * *$ & -0.035 & $0.602 *$ \\
\hline 2. Paired testis weight & - & $\ldots$ & $0.872 * *$ & $0.864 * * *$ & $0.943 * * *$ & 0.148 & $0.811 * *$ \\
\hline 3. Paired epididymal weight & & & - & $0.670^{*}$ & $0.759 * *$ & 0.148 & $0.649^{*}$ \\
\hline 4. Paired tunica albuginea & & & & - & $0.860 * * *$ & -0.131 & $0.685^{*}$ \\
\hline 5. Mean testis volume & & & & & - & -0.353 & $0.830 * * *$ \\
\hline 6. Mean testis density & & & & & & _ & -0.157 \\
\hline 7. Mean epididymal length & & & & & & & - \\
\hline
\end{tabular}

$*=\mathrm{p}<0.05, * *=\mathrm{p}<0.01, * * *=\mathrm{p}<0.001$ 
ALI ABDULLAHI, I.; AL-HASSAN MUSA, H. \& JIBRIL, A. Circunferencia escrotal y características testiculares morfométricas del camello (Camelus dromedarius) en el ambiente semiárido del Norte de Nigeria. Int. J. Morphol., 30(4):1369-1372, 2012.

RESUMEN: El tracto reproductivo de 12 camellos (Camelus dromedarius) fue utilizado para evaluar la morfometría testicular. Las características morfométricas testiculares medidas fueron la circunferencia escrotal (in situ), peso testicular pareado, peso epididimario y longitud media del epidídimo, volumen y densidad testicular. No hubo diferencias significativas ( $\mathrm{p}>0,05)$ entre los órganos del lado izquierdo y derecho, aunque se observaron diferencias numéricas entre todos los parámetros. Correlaciones positivas altamente significativas ( $\mathrm{p}<0,05$, $\mathrm{p}<0,01, \mathrm{y} \mathrm{p}<0,001)$ existen entre la circunferencia escrotal, morfometría testicular y del epidídimo, a excepción de la densidad testicular que no fue significativa (p>0,05). Se concluyó que la morfometría testicular podría proporcionar información fiable para predecir la producción espermática de camellos en el ambiente semiárido.

PALABRAS CLAVE: Camellos; Circunferencia escrotal; Morfometría testicular; Epidídimo; Semiárido.

\section{REFERENCES}

Adeyemo, G. O.; Longe, O. G. \& Adejumo, D. O. The Reproductive performance of Broiler Cocks fed cottonseed cake- based diets. Int. J. Poult. Sci., 6(2):140-4, 2007.

Bitto, I. I. \& Egbunike, G. N. Seasonal variations in the morphometric characteristics of the pubertal West African Dwarf Bucks in its Native Tropical Environment. Int. J. Morphol., 24(4):637-42, 2006.

Bitto I. I. \& Okpale, M. I. Sperm production rate, Gonadal and extragonadal sperms reserves in slaughtered White Fulani (Bunaji) bulls in a lowland tropical environment. Nig. J. Anim. Prod., 33(2):300-7, 2006.

Djemali, M. \& Alhadrami, G. The future of camel is their present. Proceeding of the 3rd Annual meeting for Animal production under arid condition. United Arab Emirates University, 1998. pp.1-8.

Dyce, K. M.; Sack, W. O. \& Wensing, C. J. G. The pelvis and reproductive organs of male ruminants: in textbook of veterinary anatomy. $3^{\text {rd }}$ ed. New York, Saunders, 2002. pp.713-22.

Faye, B. \& Esenov, P. Desertification combat and food safety. The added value of camel producers. Amsterdam, IOS Press, 2005.

Knoess, K. H. Milk production of the dromedary. Sudan, Camels IFS symposium, 1979. pp.201-4.

Nwarkalor, L. N. \& Obasi, U. O. Relationship of Testicular Size, Body Measurements and Age in the White Fulani (Bunaji) and Ndama bulls. East Afr. Agric. J., 57(1):23-31, 1991.

Ogwuegbu, S. O.; Oko, B. O.; Akusu, M. O. \& Arie, T. A. Gonadal and Extragonadal Sperm Reserves of the Maradi (Red Sokoto) goats. Bull. Anim. Health Prod. Afr., 33:139-41, 1985.

Okwun, O. E.; Igboeli, G.; Ford, J. J.; Lunstra, D. D. \& Johnson, L. Number and function of Sertoli cells, number and yield of spermatogonia, and daily sperm production in three breeds of boar. J. Reprod. Fertil., 107(1):137-49, 1996.

Osinowo, E. O.; Dennis, S. M.; Osori, D. I. K. \& Molokwu, E. C. T. Scrotal and testicular dimensions in some West African bulls. Niger. J. Anim. Prod., 4(2):31-6, 1977.

Osinowo, E. O.; Molokwu, E. C. \& Osori, D. C. Growth and testicular development in Bunaji bulls. J. Anim. Res., 16:55-67, 1981.
Osman, A. M. \& el-Azab, E. A. Gonadal and epididymal sperm reserves in the camel, Camelus dromedarius. J. Reprod. Fertil., 38(2):425-30, 1974.

Setchell, B. P. The mammalian testes. London, Paul Elek, 1978.

Sisson, S. \& Crossman, J. D. The Anatomy of Domestic Animals. $4^{\text {th }}$ ed. Philadelphia, Saunders, 1969.

Skidmore, J. A. Developments in reproduction in dromedary camels. Satellite meeting on camelid reproduction, 2008. pp.10-3.

Steel, R. G. D. \& Torry, J. H. Principles and procedures of statistics. A Biometrical Approach. $3^{\text {rd }}$ ed. New York, McGraw-Hill Book Co. Inc., 1996. p.672.

Togun, V. A. \& Egbunike, G. N. Seasonal variations in the sperm production characteristics of Zebu (White Fulani) cattle genitalia in the humid tropical environment. Middle-East J. Sci. Res., 1:8795, 2006.

Togun, V. A.; Farinu, G. O. \& Olabanji, R. O. Feeding Graded Levels of Wild Sunflower (Tithonia diversifolia Hemsl. A. Gray) Meal in Replacement of Maize at Pre-pubertal Age, Negatively Impacts on Growth and Morphormetric Characteristics of the Genitalia of Anak 2000 Broiler Cocks at Their Pubertal Age. World Appl. Sci. J., 1(2) :115-21, 2006.

Togun, V. A. Testis characteristics in Bos indicus and Bos Taurus in Ibadan. PhD Thesis. Dept. Animal Science, Univ. of Ibadan, Ibadan, Nigeria, 1981.

Ugwu, S. O. C. Relationship between scrotal circumference in situ testicular measurements and sperm reserves in the West African dwarf bucks. Afr. J. Biotechnol.,8(7):1354-7, 2009.

Willis, B. M. Breeding policies in developing regions. In: Dalton's introduction to practical animal breeding. $4^{\text {th }}$ ed. Oxford, Blackwell Science, 2001. p.1328.

Correspondence to:

Ibrahim Ali Abdullahi

Department of Animal Science

Kano University of Science and Technology

Wudil, Kano State

NIGERIA

Email: talk2aai@yahoo.com

Received: $20-12-2012$

Accepted: 18-05-2012 